\title{
OBLIGACJE JAKO ŹRÓDŁO FINANSOWANIA DZIAŁALNOŚCI BANKU GOSPODARSTWA KRAJOWEGO
}

\begin{abstract}
\section{Bonds as a source of financing Bank Gospodarstwa Krajowego}

The main purpose of this article is to characterize specifics form of Bank Gospodarstwa Krajowego (BGK) functioning as a bond issuer. Moreover, the specific purpose is to determine whether Bank Gospodarstwa Krajowego is financed by bonds in greater extent than the commercial banks. To achieve the above purposes, the author used the literature review and legal acts review supplemented by analyses of the BGK and commercial banks information documents, as well as desk research including the analysis of data from the financial statements of the BGK and aggregated data of the commercial banks sector in Poland.
\end{abstract}

Keywords: development bank, BGK, bank bonds, bond issues

\section{Streszczenie}

Celem niniejszego artykułu jest charakterystyka specyfiki funkcjonowania Banku Gospodarstwa Krajowego (BGK) jako emitenta obligacji. Ponadto celem szczegółowym jest ustalenie czy BGK finansuje się obligacjami w większym stopniu niż ma to miejsce w przypadku banków komercyjnych. Aby zrealizować wyżej wyszczególnione cele, autor posłużył się badaniem literatury przedmiotu i aktów prawnych uzupełnionym o badanie dokumentów informacyjnych BGK i banków komercyjnych oraz desk research obejmujący analizę danych ze sprawozdań finansowych BGK oraz zagregowanych danych dot. sektora banków komercyjnych w Polsce.

Słowa kluczowe: bank rozwoju, BGK, obligacje bankowe, emisje obligacji 


\section{Wstęp}

Działalność Banku Gospodarstwa Krajowego (dalej: BGK), który jest jedynym państwowym bankiem rozwoju w Polsce, odgrywa ważną rolę w kontekście realizacji zadań sektora publicznego, a także rozwoju społeczno-gospodarczego kraju. Sprawia to, że zarówno zakres funkcjonowania tego banku, jak i źródła jego finansowania stanowią interesujący obszar badawczy. Z perspektywy niniejszego artykułu szczególnie istotną formą finansowania BGK jest emisja obligacji. Wynika to z tego, że wartość rynkowa obligacji BGK, które pod koniec 2019 roku były notowane na rynku obligacji Catalyst, stanowiły 13,8\% wartości tego rynku, z wyłączeniem obligacji emitowanych przez Skarb Państwa, a także $18,8 \%$ rynku obligacji wyemitowanych przez banki. Tym samym BGK - z wyłączeniem Skarbu Państwa - był najaktywniejszym krajowym emitentem obligacji na rynku obligacji Catalyst.

Biorąc powyższe pod uwagę, celem artykułu jest charakterystyka specyfiki funkcjonowania BGK jako emitenta obligacji bankowych. Celem szczegółowym jest z kolei ustalenie, czy BGK finansuje swoją działalność obligacjami w większym stopniu, niż ma to miejsce w przypadku banków komercyjnych. Dodatkowo zgodnie z eksplanacyjną funkcją nauki - autor wyjaśni różnice w zakresie stopnia finansowania działalności obligacjami banków komercyjnych oraz państwowego banku rozwoju. Aby zrealizować główny cel opracowania, wykorzystane zostanie badanie dokumentów informacyjnych BGK, a także analiza dokumentów informacyjnych banków komercyjnych, mająca za zadanie wyselekcjonowanie celów emisji obligacji przez te podmioty. Cel szczegółowy zostanie zrealizowany $\mathrm{z}$ wykorzystaniem zestawienia danych dotyczących stopnia finansowania obligacjami BGK oraz zagregowanych danych w zakresie stopnia finansowania obligacjami banków komercyjnych w Polsce.

W opinii autora ze względu na dużą aktywność BGK na rynku obligacji Catalyst zrozumienie specyfiki działania tego podmiotu i determinantów jego finansowania przez emisję obligacji pozwoli na lepsze zrozumienie funkcjonowania całego rynku obligacji nieskarbowych Catalyst. Jest to istotne, zwłaszcza biorąc pod uwagę to, że coraz częściej poruszanymi zagadnieniami w literaturze przedmiotu są uwarunkowania rozwoju rynku obligacji bankowych (zwłaszcza w kontekście obligacji podporządkowanych czy stosunkowo nowej kategorii długu w Polsce - obligacji nieuprzywilejowanych). Niniejsze opracowanie uzupełnia zatem lukę badawczą w zakresie uwarunkowań finansowania obligacjami państwowego banku rozwoju.

\section{Działalność i źródła finansowania banku rozwoju w Polsce}

BGK powstał w 1924 roku w wyniku połączenia trzech publicznych instytucji kredytowych. Pierwszy prezes BGK na inauguracyjnym wystąpieniu podczas 
posiedzenia rady nadzorczej stwierdził, że „Bank Gospodarstwa Krajowego jest uzupełnieniem organizacji kredytowej, a powstał $\mathrm{z}$ wyczucia potrzeby stworzenia instytucji, która udzielałaby długoterminowego kredytu i ożywiła nasze życie gospodarcze" [BGK, 1924]. Idea ożywienia gospodarki krajowej towarzyszyła BGK nieprzerwanie od 1924 roku. Tym samym niezmienna pozostaje również misja BGK, którą jest „wspieranie rozwoju społeczno-gospodarczego Polski oraz sektora finansów publicznych w realizacji jego zadań" [BGK, 2020]. Pod szeroko zdefiniowaną misją kryją się konkretne cele, które wynikają z ustawy regulującej działalność tego banku. Do celów tych zalicza się wspieranie polityki gospodarczej Rady Ministrów, rządowych programów społeczno-gospodarczych, w tym poręczeniowo-gwarancyjnych, oraz programów samorządności lokalnej i rozwoju regionalnego, obejmujących w szczególności projekty (zob. art. 4 ustawy z dnia 14 marca 2003 roku o Banku Gospodarstwa Krajowego, Dz.U. 2003, nr 65, poz. 594, dalej: ustawa o BGK):

- realizowane z wykorzystaniem środków pochodzących z funduszy Unii Europejskiej oraz międzynarodowych instytucji finansowych;

- infrastrukturalne;

- związane z rozwojem sektora mikroprzedsiębiorców, małych i średnich przedsiębiorców.

Ustawa w art. 5 wyszczególnia również konkretne zadania BGK, do których należą między innymi:

- obsługa funduszy utworzonych, powierzonych lub przekazanych BGK na podstawie odrębnych ustaw;

- obsługa transakcji eksportowych z zastosowaniem instrumentów wspierania eksportu oraz wspieranie eksportu polskich towarów i usług;

- prowadzenie - bezpośrednio lub pośrednio - działalności gwarancyjnej lub poręczeniowej w ramach realizacji rządowych programów poręczeniowo-gwarancyjnych;

- wspieranie rozwoju budownictwa mieszkaniowego, w szczególności budownictwa mającego na celu budowę lokali mieszkalnych na wynajem, zgodnie $\mathrm{z}$ odrębnymi przepisami lub $\mathrm{w}$ ramach realizacji rządowych programów;

- prowadzenie działalności bankowej określonej ustawą z dnia 29 sierpnia 1997 roku - Prawo bankowe (Dz.U. 1997, nr 140, poz. 939, dalej: Prawo bankowe)

Z zadań BGK w kontekście niniejszego artykułu szczególne znaczenie ma obsługa funduszy. Wynika to z tego, że BGK może emitować obligacje w celu sfinansowania zarządzanych przez siebie funduszy. A zatem poza finansowaniem bieżącej działalności i utrzymywaniem płynności finansowej BGK może emitować obligacje również na poczet finansowania działalności funduszy. Dotychczas bank finansował w ten sposób wyłącznie działalność Krajowego Funduszu Drogowego (dalej: KFD). Fundusz ten został utworzony w celu usprawnienia procesu inwestycyjnego budowy dróg krajowych oraz bardziej efektywnego wykorzystania środków publicznych dzięki wsparciu rządowego programu budowy dróg krajowych. Chociaż podstawowym źródłem zasilania funduszu jest udział 
we wpływach z opłaty paliwowej ( $80 \%$ tych wpływów) oraz wpływy z poboru opłat za przejazd po drogach krajowych, a także opłat za przejazd płatnymi odcinkami autostrad, to do istotnych źródeł finansowania KFD zalicza się także wpływy z emisji obligacji przeprowadzonych przez BGK. Co ważne, za zobowiązania banku z tytułu wyemitowanych obligacji mogą być udzielane gwarancje i poręczenia przez Skarb Państwa. Gwarancje i poręczenia są w tym wypadku zwolnione z opłat prowizyjnych (zob. art. 39b-39d ustawy z dnia 27 października 1994 roku o autostradach płatnych oraz o Krajowym Funduszu Drogowym, Dz.U. 1994, nr 127, poz. 627).

Nie mniej istotne są kwestie związane ze źródłami finansowania samego BGK. I tak art. 5 ustawy o BGK stanowi, że w celu realizacji programów rządowych minister właściwy do spraw finansów publicznych przekazuje środki na zwiększenie funduszu statutowego BGK. Minister ten może również przekazać skarbowe papiery wartościowe na zwiększenie funduszu statutowego BGK oraz udzielić bankowi pożyczki ze środków budżetu państwa na zwiększenie funduszy własnych. Dodatkowo BGK może pozyskiwać środki finansowe z innych źródeł, w szczególności zaciągać kredyty i pożyczki oraz emitować listy zastawne i obligacje, a także przeznaczać zysk netto na zwiększenie funduszy własnych (zob. art. 5 ustawy o BGK). Niemniej w sytuacji gdy BGK posiada fundusze własne na poziomie wyższym niż poziom, który bank jest zobowiązany utrzymywać zgodnie z ustawą Prawo bankowe oraz wymogami ostrożnościowymi, minister właściwy do spraw instytucji finansowych może obniżyć fundusz statutowy BGK.

Co ciekawe, w celu utrzymania płynności finansowej BGK Skarb Państwa może odpłatnie udzielić gwarancji spłaty wyemitowanych przez bank obligacji. Niemniej termin zapadalności tych papierów wartościowych nie może być krótszy niż miesiąc i dłuższy niż pięć lat (zob. art. 3a ustawy o BGK). Zabezpieczenie wykupu obligacji (zwłaszcza przez Skarb Państwa) skutkuje dla inwestorów niższym ryzykiem kredytowym, co explicite przekłada się na niższe koszty finansowania ponoszone przez emitenta.

\section{Determinanty finansowania działalności banków obligacjami}

Rozpatrując determinanty finansowania działalności banków obligacjami warto wyodrębnić poszczególne rodzaje tych dłużnych papierów wartościowych. I tak poza najczęściej wymienianymi kategoriami obligacji, takimi jak rodzaj emitenta, rodzaj świadczenia przysługującego obligatariuszom, rodzaj oprocentowania, termin wykupu, zabezpieczenie czy poziom ryzyka inwestycyjnego [Parameswaran, 2011: 167-169], w przypadku obligacji bankowych szczególnie istotne jest kryterium hierarchii zaspokajania obligatariuszy w przypadku upadłości banku. 


\section{Obligacje senioralne}

\section{Obligacje nieuprzywilejowane}

\section{Obligacje podporządkowane}

Rys. 1. Kolejność zaspokajania poszczególnego rodzaju obligatariuszy w przypadku upadłości banku

Źródło: opracowanie własne na podstawie ustawy z dnia 28 lutego 2003 roku Prawo upadłościowe, Dz.U. 2003, nr 60, poz. 535 oraz Rozporządzenia Parlamentu Europejskiego i Rady nr 575/2013 w sprawie wymogów ostrożnościowych dla instytucji kredytowych i firm inwestycyjnych.

Najwyższym stopniem uprzywilejowania w przypadku upadłości banku lub wszczęcia wobec niego procedury przymusowej restrukturyzacji (ang. resolution) ${ }^{1}$ cechują się obligacje senioralne. Jest to najczęściej spotykana forma obligacji (nazywana również obligacjami tradycyjnymi lub klasycznymi), która nie wymaga szczegółowej charakterystyki. Banki decydują się na emisję tych papierów wartościowych głównie ze względu na uwarunkowania ekonomiczne. Kolejną grupą obligacji, wyszczególnioną na rys. 1, są obligacje nieuprzywilejowane (ang. senior non-preferred bonds). Różnice między obligacjami nieuprzywilejowanymi a obligacjami senioralnymi występują głównie w kolejności zaspokajania wierzycieli w przypadku upadłości banku. Biorąc powyższe pod uwagę, w razie upadłości banku lub wszczęcia wobec niego procedury resolution obligacje te będę spłacane po zaspokojeniu roszczeń obligatariuszy senioralnych. Jeszcze niższym stopniem uprzywilejowania cechują się popularne w Polsce obligacje podporządkowane. Są one definiowane jako dłużne instrumenty finansowe, przy emisji których emitent postanawia, że wierzy telności wynikające z emitowanych przez niego obligacji w przypadku upadłości lub likwidacji będą zaspokojone po zaspokojeniu wszystkich innych wierzytelności przysługujących wierzycielom wobec tego emitenta (zob. art. 22 ustawy z dnia 15 stycznia 2015 roku o obligacjach, Dz.U. 2015, poz. 238). Jedynie obligacje odwrotnie zamienne zwane CoCo (ang. contingentconvertible bonds) cechują się większym ryzykiem w zakresie prawdopodobieństwa braku spłaty obligatariuszy w przypadku upadłości banku [Małek, Szelągowska, 2018: 88]. Niemniej specyficzne cechy tych obligacji, to jest zmiana charakteru $z$ instrumentu dłużnego na udziałowy po zaistnieniu określonych zdarzeń, sprawia, że instrumenty te są często klasyfikowane jako kapitał własny banku [Dunilec, 2001: 158-161].

Z wyjątkiem obligacji senioralnych banki decydują się najczęściej na emisję obligacji ze względów regulacyjnych. Pierwszym z regulacyjnych czynników

${ }^{1}$ Przymusowa restrukturyzacja (ang. resolution) jest uregulowanym przez prawo postępowaniem prowadzonym wobec zagrożonych upadłością instytucji kredytowych lub firm inwestycyjnych. 
finansowania działalności banków obligacjami jest możliwość spełnienia tak zwanego wymogu MREL, to jest minimalnego poziomu funduszy własnych i zobowiązań podlegających umorzeniu lub konwersji (ang. Minimum Requirement for own funds and Eligible Liabilities) przez emisję obligacji nieuprzywilejowanych lub podporządkowanych. Wymóg MREL ma zapewnić, że w procesie przymusowej restrukturyzacji możliwe będzie umorzenie lub konwersja długu banków, rozumiana jako zamiana instrumentów dłużnych na inne instrumenty finansowe (na przykład akcje). Zakres podmiotowy MREL obejmuje przy tym wszystkie banki w całej Unii Europejskiej [Cross, 2017]. Banki będą miały czas na osiągnięcie wyznaczonego poziomu MREL do 1 stycznia 2023 roku. Szacuje się przy tym, że luka MREL w Polsce mieści się w przedziale od $50 \mathrm{mld}$ zł do $100 \mathrm{mld}$ zł [PWC, 2018].

Drugim czynnikiem regulacyjnym jest możliwość zaliczania wyemitowanych przez bank obligacji podporządkowanych do funduszy własnych banku. To z kolei umożliwia bankom spełnienie restrykcyjnych wymogów regulacyjnych w zakresie kształtowania się poziomu tych funduszy. Krzysztof Jackowicz podkreśla przy tym, że obligacje podporządkowane - pomimo zwiększania dźwigni finansowej - stanowią stabilne źródło finansowania banku. Co więcej autor ten uważa, że rynkowy poziom cen obligacji podporządkowanych odzwierciedla kondycję finansową ich emitenta lepiej, niż ma to miejsce w przypadku akcji [Jackowicz, 2004: 253]. Warto przy tym zaznaczyć, że obligacje podporządkowane, które za zgodą KNF zostaną zaliczone do funduszy własnych banku, obniżają również podstawę opodatkowania podatkiem od niektórych instytucji finansowych (tak zwany podatek bankowy) ${ }^{2}$.

Doszukując się stricte ekonomicznych determinantów finansowania banków przez emisję obligacji, należy podkreślić, że emisja obligacji stanowi elastyczne źródło finansowania, dającą możliwość dostosowania wielkości i okresu kredytowania według uznania emitenta [Antkiewicz, 2011: 44]. Dodatkowo obligacje dają bankom możliwość dywersyfikacji źródeł finansowania. Jest to szczególnie istotne biorąc pod uwagę to, że w strukturze źródeł finansowania działalności banków komercyjnych znaczący udział mają depozyty krótkoterminowe. Zgodnie z danymi publikowanymi przez Komisję Nadzoru Finansowego (dalej: KNF), według stanu na grudzień 2019 roku, blisko 74\% pasywów banków komercyjnych stanowiły depozyty [KNF, 2020]. Tak wysoki udział krótkoterminowych źródeł finansowania stwarza zagrożenie ujemnej luki płynnościowej, definiowanej jako niedobór środków pieniężnych do wywiązywania się banku z wymagalnych płatności w danym okresie [Iwanicz-Drozdowska i in., 2010: 246]. Obligacje są zatem ważnym narzędziem w kontekście wydłużania średniego terminu zapadalności zobowiązań banków. Odległe terminy zapadalności tych instrumentów mogą przyczyniać się przy tym do redukcji ryzyka utraty płynności, wynikającego

${ }^{2}$ Efekt ten nie ma jednak zastosowania w przypadku banków objętych planem naprawy, planem naprawczym lub programem postępowania naprawczego, które w myśl ustawy z dnia 15 stycznia 2016 roku o podatku od niektórych instytucji finansowych (Dz.U. 2016, poz. 68, dalej: o podatku od niektórych instytucji finansowych) są zwolnione z tego podatku. 
z niedopasowania terminów spłaty kredytów i depozytów bankowych [Papież, 2015]. Dodatkowo - tak jak w przypadku pozostałych kapitałów obcych - odsetki, które bank wypłaca od obligacji (z wyjątkiem obligacji dyskontowych), stanowią koszty finansowe, zmniejszając tym samym podstawę opodatkowania dochodów banku [Antkiewicz, 2011: 38].

W celu zidentyfikowania powodów emitowania obligacji przez banki komercyjne autor dokonał analizy dokumentów informacyjnych tych instytucji. Dotyczy to tych serii obligacji, które pod koniec 2019 roku były notowane na rynku Catalyst. Warto zaznaczyć, że pod względem wartości nominalnej obligacji banków komercyjnych według stanu pod koniec 2019 roku niemalże 69\% stanowiły obligacje podporządkowane. Pozostałe $31 \%$ były obligacjami senioralnymi (wedle stanu na koniec 2019 roku żaden bank komercyjny w Polsce nie zdecydował się na emisję obligacji nieuprzywilejowanych). Wszystkie obligacje wyemitowane przez BGK były zaś obligacjami senioralnymi. Podział wyemitowanych obligacji na senioralne oraz podporządkowane jest bardzo istotny, biorąc pod uwagę to, że każdej z tych grup obligacji przypisać można zgoła odmienne cele emisji deklarowane przez emitentów. I tak badanie empiryczne dokumentów informacyjnych banków komercyjnych pokazuje, że wszystkie bankowe obligacje podporządkowane zostały wyemitowane w celu zwiększenia funduszy własnych (uzupełniających) banku. Z tego 13,3\% obligacji podporządkowanych pod względem wartości nominalnej było wyemitowanych również w celu zwiększenia skali działalności banku. W zakresie obligacji senioralnych w $95 \%$ pod względem wartości nominalnej tych papierów wartościowych emitenci nie określili celu emisji. W przypadku pozostałych 5\% celem emisji było pozyskanie środków finansowych na potrzeby bieżącej działalności banku. W zakresie obligacji emitowanych przez BGK w przypadku $51 \%$ obligacje były emitowane na potrzeby KFD. W odniesieniu do pozostałych $49 \%$ obligacji emitent nie wyszczególnił zaś żadnego celu emisji.

Powyższe pozwala na wyodrębnienie kilku unikatowych względem banków komercyjnych cech BGK, które sprawiają, że podmiot ten może być uznany za specyficzny emitent obligacji bankowych. Do tych cech zaliczyć można:

- Konieczność obsługi przez BGK różnego typu funduszy, w szczególności $\mathrm{KFD}$, który jest $\mathrm{w}$ dużej mierze finansowany środkami $\mathrm{z}$ emisji obligacji (zob. art. 5 ustawy o BGK).

- Wobec BGK nie stosuje się zapisów ustawy z dnia 10 czerwca 2016 roku o Bankowym Funduszu Gwarancyjnym, systemie gwarantowania depozytów oraz przymusowej restrukturyzacji (Dz.U. 2016, poz. 996, dalej: ustawa o BFG; zob. art. 1). Implikuje to brak konieczności spełnienia przez BGK wymogu MREL. Ten z kolei - zgodnie z wnioskami zawartymi w Raporcie o stabilności systemu finansowego za 2018 rok - będzie determinował w głównej mierze emisję obligacji nieuprzywilejowanych przez banki [NBP, 2018].

- Zgodnie z art. 5 ustawy o BGK minister właściwy do spraw finansów publicznych może przekazać bankowi środki lub skarbowe papiery wartościowe $\mathrm{w}$ celu zwiększenie funduszu statutowego banku (art. 5 ustawy o BGK). W związku z tym BGK nie posiada presji na zwiększanie 
poziomu funduszy własnych. Zwiększanie funduszy własnych - a tym samym współczynników wypłacalności finansowej - determinuje zaś chęć emisji obligacji podporządkowanych przez banki komercyjne.

- Dodatkowo BGK jest zwolniony z podatku od niektórych instytucji finansowych. Tym samym nie zachodzi tutaj mechanizm, przez który zaliczenie przez BGK obligacji podporządkowanych do funduszy własnych zmniejszałoby podstawę opodatkowania podatkiem od niektórych instytucji finansowych (art. 10 ustawy z dnia 15 stycznia 2016 roku o podatku od niektórych instytucji finansowych, Dz.U. 2016, poz. 68, dalej: ustawa o podatku od niektórych instytucji finansowych).

Wyżej wymienione unikatowe cechy świadczą o tym, że większość zachęt regulacyjnych skłaniających banki komercyjne do emitowania długu podporządkowanego lub nieuprzywilejowanego nie ma zastosowania względem BGK.

\section{Stopień finansowania banków przez emisję obligacji}

Z danych publikowanych przez KNF wynika, że wzrostowi sumy bilansowej banków komercyjnych w latach 2012-2019 towarzyszył wzrost wartości zobowiązań z tytułu emisji obligacji. Wartość nominalna wyemitowanych obligacji w tym okresie wzrosła z 52,3 mld zł do 91,3 mld zł. Co więcej wskaźnik CAGR ${ }^{3}$ dotyczący wartości zobowiązań banków z tytułu emisji obligacji w okresie ostatnich ośmiu lat (tj. od początku 2012 roku do końca 2019 roku) wynosił 8,6\%. W tym samym czasie suma bilansowa banków komercyjnych rosła w wolniejszym tempie, o czym świadczy wskaźnik CAGR w wysokości 5,6\%.

Tabela 1.

Finansowanie obligacjami banków komercyjnych w Polsce w latach 2012-2019 (mld PLN)

\begin{tabular}{|l|c|c|c|c|c|c|c|c|}
\hline \multicolumn{1}{|c|}{ Banki komercyjne (mId PLN) } & $\mathbf{2 0 1 2}$ & $\mathbf{2 0 1 3}$ & $\mathbf{2 0 1 4}$ & $\mathbf{2 0 1 5}$ & $\mathbf{2 0 1 6}$ & $\mathbf{2 0 1 7}$ & $\mathbf{2 0 1 8}$ & $\mathbf{2 0 1 9}$ \\
\hline Zobowiązania z tytułu emisji obligacji & 52,3 & 53,4 & 53,9 & 57,1 & 66,7 & 84,8 & 86,3 & 91,3 \\
\hline Suma pasywów & 1232 & 1273 & 1390 & 1454 & 1549 & 1602 & 1690 & 1781 \\
\hline Udział obligacji w pasywach [\%] & 4,2 & 4,2 & 3,9 & 3,9 & 4,3 & 5,3 & 5,1 & 5,1 \\
\hline
\end{tabular}

Źródło: opracowanie własne na podstawie danych miesięcznych sektora bankowego KNF za grudzień 2019.

Do oceny tego, które czynniki determinowały tak szybki wzrost wartości wyemitowanych obligacji banków komercyjnych, istotny byłby podział tych instrumentów

${ }^{3}$ Ang. Compound Annual Growth Rate - skumulowany roczny wskaźnik wzrostu, obliczany zgodnie ze wzorem: $\operatorname{CAGR}\left(\mathrm{t}_{0}-\mathrm{t}_{1}\right)=[$ wykres $]-1$, gdzie: $\mathrm{n}=$ liczba okresów. 
finansowych na kategorie według kryterium kolejności zaspokajania obligatariuszy w przypadku upadłości banku.

Pomimo tego, że możliwość emitowania w Polsce obligacji nieuprzywilejowanych pojawiła się z początkiem 2019 roku, kiedy to 12 lutego prezydent podpisał ustawę o zmianie ustawy o BFG, systemie gwarantowania depozytów oraz przymusowej restrukturyzacji oraz niektórych innych ustaw (Dz.U. 2019, poz. 326), to według stanu na koniec 2019 roku żaden bank w Polsce nie wyemitował tego typu obligacji. W związku z tym na obligacje emitowane przez banki komercyjne w Polsce składają się wyłącznie obligacje senioralne, przy emisji których banki kierują się czynnikami stricte ekonomicznymi, oraz obligacje podporządkowane, których rozwój jest determinowany czynnikami regulacyjnymi.

Jako że nie wszystkie emisje obligacji są emisjami publicznymi, nie ma możliwości dokładnego określenia udziału obligacji senioralnych i podporządkowanych. W tym celu autor posłużył się danymi z rynku obligacji Catalyst.

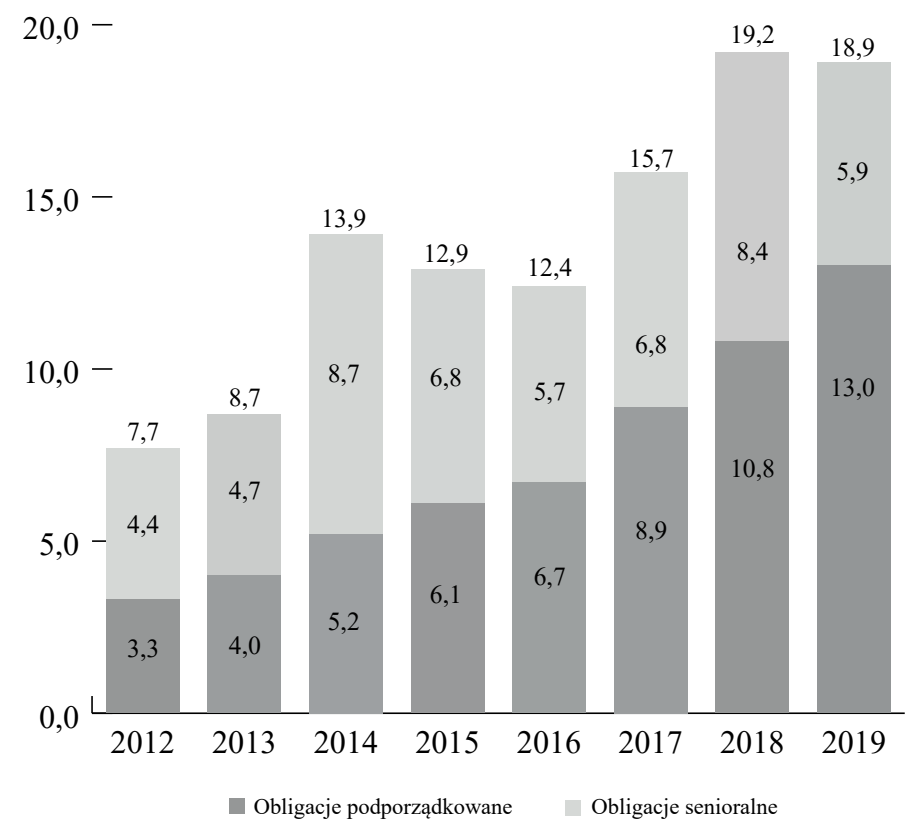

Wykres 1 . Wartość nominalna obligacji wyemitowanych przez banki komercyjne i notowanych na rynku Catalyst w latach 2012-2019 (mld PLN)

Źródło: opracowanie własne na podstawie danych z rynku Catalyst.

Zgodnie z wykresem 1 na rynku Catalyst pod koniec 2019 roku wartość obligacji podporządkowanych stanowiła ponad dwie trzecie wartości rynku obligacji wyemitowanych przez banki komercyjne (68,9\%). Warto podkreślić, że wartość 
obligacji podporządkowanych rosła dużo szybciej (CAGR w latach 2012-2019 na poziomie $21,6 \%$ ) niż wartość obligacji senioralnych (CAGR w tym samym okresie na poziomie 4,1\%). Co więcej, wartość obligacji senioralnych pod koniec 2019 roku (5,9 mld zł) była najniższa od 2014 roku. Oznacza to, że wzrost rynku obligacji banków komercyjnych wynikał w głównej mierze ze wzrostu wartości obligacji podporządkowanych.

Tak jak w przypadku danych finansowych banków komercyjnych również suma bilansowa BGK w okresie od końca 2012 roku do końca trzeciego kwartału 2019 roku wzrosła - przy czym był to szybszy wzrost niż w przypadku banków komercyjnych - z 48,7 mld zł do 135,7 mld zł. Trendem wzrostowym charakteryzowała się również wartość zobowiązań BGK z tytułu emisji obligacji, które wzrosły z 4,6 mld zł pod koniec 2012 roku do 5,9 mld zł pod koniec trzeciego kwartału 2019 roku (CAGR na poziomie 3,9\%). Warto podkreślić, że jest to ponad dwa razy wolniejsze tempo wzrostu niż w przypadku wartości obligacji wyemitowanych przez banki komercyjne.

Tabela 2.

Finansowanie obligacjami BGK w latach 2012-2019Q3 (mld PLN)

\begin{tabular}{|l|c|c|c|c|c|c|c|c|}
\hline \multicolumn{1}{|c|}{ BGK (mId PLN) } & $\mathbf{2 0 1 2}$ & $\mathbf{2 0 1 3}$ & $\mathbf{2 0 1 4}$ & $\mathbf{2 0 1 5}$ & $\mathbf{2 0 1 6}$ & $\mathbf{2 0 1 7}$ & $\mathbf{2 0 1 8}$ & $\mathbf{2 0 1 9 Q 3}$ \\
\hline Zobowiązania z tytułu emisji obligacji & 4,6 & 4,5 & 5,4 & 5,8 & 5,8 & 6,3 & 5,8 & 5,9 \\
\hline Suma pasywów & 48,7 & 43,8 & 51,2 & 43,4 & 67,3 & 74,3 & 84,7 & 135,7 \\
\hline Udział obligacji w pasywach [\%] & 9,4 & 10,4 & 10,6 & 13,4 & 8,6 & 8,5 & 6,8 & 4,3 \\
\hline
\end{tabular}

Źródło: opracowanie własne na podstawie kwartalnych danych bilansowych BGK.

Dynamiczny wzrost sumy bilansowej BGK oraz wolniejszy niż w przypadku banków komercyjnych wzrost wartości wyemitowanych obligacji przekładał się na zmniejszenie udziału obligacji w pasywach państwowego banku rozwoju. Udział ten zmalał z 9,4\% pod koniec 2012 roku do niespełna 4,3\% pod koniec trzeciego kwartału 2019 roku. Warto zaznaczyć przy tym, że wszystkie obligacje wyemitowane przez BGK były obligacjami senioralnymi. Dużo większym udziałem obligacji w sumie bilansowej charakteryzował się natomiast KFD. Na początku 2012 roku udział obligacji wynosił tam aż 58,7\% pasywów, spadając do poziomu 35,6\% pod koniec trzeciego kwartału 2019 roku. Wynikało to z malejącej wartości zobowiązań KFD z tytułu emisji obligacji w tym okresie, z 25,9 mld zł do 19 mld zł (CAGR -4,5\%). Wszystkie obligacje wyemitowane na poczet KFD były obligacjami senioralnymi z gwarancją Skarbu Państwa, co pozwalało na obniżenie koszów finansowania. 
Tabela 3.

Finansowanie obligacjami KFD w latach 2012-2019Q3 (mld PLN)

\begin{tabular}{|l|c|c|c|c|c|c|c|c|}
\hline \multicolumn{1}{|c|}{ KFD (mId PLN) } & $\mathbf{2 0 1 2}$ & $\mathbf{2 0 1 3}$ & $\mathbf{2 0 1 4}$ & $\mathbf{2 0 1 5}$ & $\mathbf{2 0 1 6}$ & $\mathbf{2 0 1 7}$ & $\mathbf{2 0 1 8}$ & $\mathbf{2 0 1 9 Q 3}$ \\
\hline Zobowiązania z tytułu emisji obligacji & 25,9 & 25,7 & 19,8 & 19,6 & 23,0 & 25,9 & 18,6 & 19,0 \\
\hline Suma pasywów & 44,2 & 45,6 & 44,6 & 45,4 & 51,8 & 57,5 & 52,9 & 53,5 \\
\hline Udział obligacji w pasywach [\%] & 58,7 & 56,5 & 44,4 & 43,1 & 44,4 & 45,0 & 35,2 & 35,6 \\
\hline
\end{tabular}

Źródło: opracowanie własne na podstawie kwartalnych danych bilansowych BGK.

Dane zawarte w tabeli 3 pokazują, że udział obligacji banków komercyjnych w pasywach systematycznie rośnie, a udział obligacji BGK w pasywach charakteryzuje się dynamicznym trendem spadkowym. Wynika to zarówno z szybkiego tempa wzrostu sumy bilansowej BGK, jak i z wolnego tempa wzrostu zobowiązań z tytułu emisji obligacji (CAGR 3,9\%), który jest zbliżony do tempa wzrostu obligacji senioralnych banków komercyjnych z rynku Catalyst w latach 2012-2019 (CAGR 4,1\%).

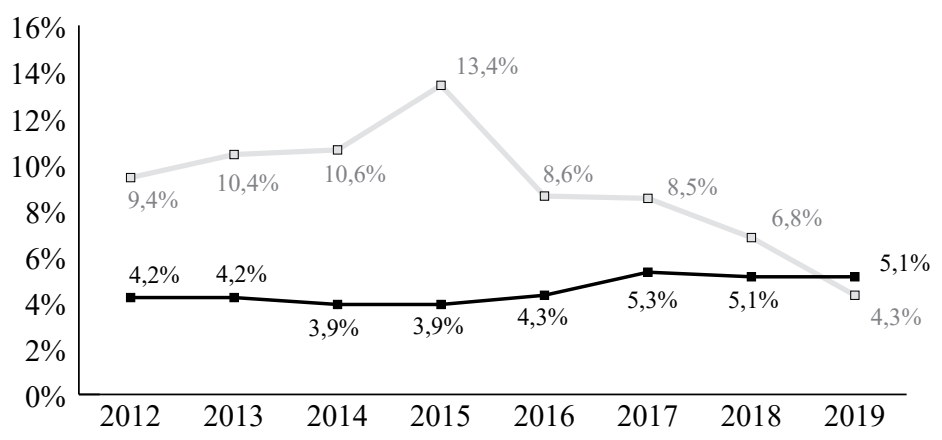

$\longrightarrow$ Banki komercyjne

BGK

Wykres 2. Porównanie procentowego udziału wyemitowanych obligacji do sumy bilansowej BGK i banków komercyjnych w Polsce w latach 2012-2019Q3

Źródło: opracowanie własne na podstawie danych KNF i BGK.

Biorąc pod uwagę to, że wartości obligacji senioralnych wyemitowanych przez banki komercyjne oraz BGK cechują się zbliżonym tempem wzrostu, przyczyn większego udziału obligacji w pasywach banków komercyjnych należy upatrywać w dynamicznym rozwoju rynku obligacji podporządkowanych. Co ważne, banki decydują się na emisję tych instrumentów finansowych głównie ze względu na czynniki regulacyjne, takie jak możliwość podniesienia poziomu funduszy 
własnych czy spełnienie wymogu MREL. Z tego samego powodu można założyć, że zarówno obligacje podporządkowane, jak i - w przyszłości - obligacje nieuprzywilejowane $\mathrm{w}$ dalszym ciągu będą stanowiły dynamicznie rozwijający się segment obligacji bankowych w Polsce. To z kolei wpłynie na wzrost dysproporcji w zakresie udziału finansowania swojej działalności obligacjami, na korzyść banków komercyjnych.

\section{Podsumowanie}

W nawiązaniu do głównego celu niniejszego artykułu autor dokonał charakterystyki specyfiki funkcjonowania BGK jako emitenta obligacji. Pozwoliło to na zidentyfikowanie specyficznych cech BGK, które odróżniają go od emitentów obligacji będących bankami komercyjnymi. Do cech tych zaliczyć można obsługę przez BGK różnego typu funduszy (w tym KFD), brak zastosowania wobec banku zapisów ustawy o BFG oraz ustawy o podatku od niektórych instytucji finansowych, a także brak presji na zwiększanie funduszy własnych. Ponadto zgodnie z celem szczegółowym opracowania autor ustalił, że udział obligacji w pasywach BGK od 2012 roku znacząco spadał, a pod koniec trzeciego kwartału 2019 roku ukształtował się na poziomie $4,3 \%$ i był niższy niż w przypadku banków komercyjnych $(5,1 \%)$. Jedną z przyczyn tego stanu jest dynamiczny wzrost wartości rynku obligacji podporządkowanych emitowanych przez banki komercyjne. Warto podkreślić, że regulacyjne determinanty finansowania banków komercyjnych przez emisję obligacji podporządkowanych nie mają zastosowania wobec BGK.

Dodatkowo w opinii autora przyszłościowym dłużnym instrumentem finansowym z perspektywy banków rozwoju wydają się zielone obligacje. Obligacje te są definiowane jako papiery wartościowe, $\mathrm{z}$ których wpływy wykorzystywane są do pełnego lub częściowego finansowania bądź refinansowania nowych lub istniejących zielonych projektów [ICMA, 2018]. Według stanu na koniec 2019 roku wartość wyemitowanych zielonych obligacji w Europie wyniosła 271 mld EUR, a za ponad połową emisji tych instrumentów finansowych stoją właśnie instytucje publiczne [ESMA, 2020]. Uwzględniając znaczny nacisk europejskich banków rozwoju na kwestie związane ze zrównoważonym rozwojem, istnieje duże prawdopodobieństwo, że zielone obligacje staną się ważnym narzędziem zapewniającym finansowanie proekologicznych inwestycji. Oczywiście, instrumenty te mogą być również emitowane przez banki komercyjne. Niemniej na zainteresowanie banków zielonymi obligacjami istotny wpływ będą miały rozwiązania legislacyjne zachęcające je do emitowania tych instrumentów finansowych.

W opinii autora to właśnie kwestia uwarunkowań rozwoju rynku zielonych obligacji wymaga dodatkowego omówienia. Szczególnie interesującym obszarem badawczym wydają się przy tym identyfikacja i możliwość likwidacji barier ograniczających potencjał rozwoju tego segmentu rynku obligacji bankowych. 


\section{Bibliografia}

Antkiewicz S. (2011), Polski rynek obligacji i innych papierów wartościowych, Wydawnictwo Uniwersytetu Gdańskiego, Gdańsk.

BGK [Bank Gospodarstwa Krajowego] (1924), Protokót pierwszego posiedzenia Rady Nadzorczej BGK, odbytego w gmachu Ministerstwa Skarbu w Warszawie w dniu 03.06.1924 r. Archiwum Akt Nowych w Warszawie (AAN, BGK).

Cross G. (2017), Banks, Private Money Creation, and Regulatory Reform, „Journal of Financial Regulation and Compliance", 1 (26).

Dunilec A. (2001), Finansowanie przedsiębiorstwa. Strategie i instrumenty, Polskie Wydawnictwo Ekonomiczne, Warszawa.

ESMA [European Securities and Markets Authority] (2020), TRV-ESMA Report on Trends, Risks and Vulnerabilities, https:/www.esma.europa.eu/sites/default/files/library/esma_50165-1040_trv_no.1_2020.pdf [dostęp: 14.03.2020].

ICMA [International Capital Market Association] (2018), The Green Bond Principles: Voluntary Process Guidelines for Issuing Green Bonds, https://www.icmagroup.org/assets/documents/Regulatory/Green-Bonds/June-2018/Green-Bond-Principles---June-2018-140618WEB.pdf [dostęp: 14.03.2020].

Iwanicz-Drozdowska M., Jaworski W.L., Zawadzka Z. (2010), Bankowość-zagadnienia podstawowe, Wydawnictwo Poltext, Warszawa.

Jackowicz K. (2004), Dyscyplina rynkowa w bankowości - rodzaje i możliwości zastosowania, Wydawnictwo Wyższej Szkoły Przedsiębiorczości i Zarządzania im. Leona Koźmińskiego, Warszawa.

KNF [Komisja Nadzoru Finansowego] (2020), Dane miesięczne sektora bankowego, https://www.knf.gov.pl/?articleId=56224\&p_id=18 [dostęp: 14.03.2020].

Małek M., Szelągowska A. (2018), Wykorzystanie obligacji typu CoCo w dynamicznej regulacji instytucji sektora bankowego, „Studia Ekonomiczne. Zeszyty Naukowe Uniwersytetu Ekonomicznego w Katowicach", 370.

NBP [Narodowy Bank Polski] (2018), Raport o stabilności systemu finansowego, https://www. nbp.pl/systemfinansowy/rsf122018.pdf [dostęp: 10.03.2020].

Papież P. (2015), Obligacje bankowe jako narzędzie wydtużania średniego terminu wymagalności pasywów banków w Polsce, „Annales Universitatis Mariae Curie-Skłodowska, sectio H - Oeconomia", 4 (49).

Parameswaran S.K. (2011), Fundamentals of Financial Instruments: An Introduction to Stocks, Bonds, Foreign Exchange, and Derivatives, John Wiley \& Sons (Asia), Singapore.

PWC (2018), Alert Regulacji Bankowych-zmiany regulacyjne w okresie od 1 listopada 2017 r. do 31 stycznia 2018 r., https://www.pwc.pl/pl/pdf/alert-regulacji-bankowych/alert-regulacji-bankowych-luty2018-pl.pdf [dostęp: 19.06.2019].

Strona Banku Gospodarstwa Krajowego (2020), https://www.bgk.pl/o-banku/misja/ [dostęp: 6.03.2020]. 


\section{Akty prawne}

Rozporządzenie Parlamentu Europejskiego i Rady nr 575/2013 w sprawie wymogów ostrożnościowych dla instytucji kredytowych i firm inwestycyjnych.

Ustawa z dnia 10 czerwca 2016 roku o Bankowym Funduszu Gwarancyjnym, systemie gwarantowania depozytów oraz przymusowej restrukturyzacji, Dz.U. 2016, poz. 996.

Ustawa z dnia 14 marca 2003 roku o Banku Gospodarstwa Krajowego, Dz.U. 2003, nr 65, poz. 594.

Ustawa z dnia 28 lutego 2003 roku Prawo upadłościowe, Dz.U. 2003, nr 60, poz. 535.

Ustawa z dnia 15 stycznia 2015 roku o obligacjach, Dz.U. 2015, poz. 238.

Ustawa z dnia 15 stycznia 2016 roku o podatku od niektórych instytucji finansowych, Dz.U. 2016, poz. 68.

Ustawa z dnia 27 października 1994 roku o autostradach płatnych oraz o Krajowym Funduszu Drogowym, Dz.U. 1994, nr 127, poz. 627.

Ustawa z dnia 29 sierpnia 1997 roku - Prawo bankowe, Dz.U. 1997, nr 140, poz. 939. 